\title{
Transforming a wasteland to a premium sporting arena: The case of Ellis Park, Johannesburg, 1900s-1930s
}

\author{
Louis Grundlingh*
}

\begin{abstract}
One of the aims of Johannesburg's British controlled town council after the South African War (1899-1902) was to provide open public leisure spaces for its white citizens. The establishment and development of Ellis Park as a major sport centre was one of these endeavours. In 1908 the council bought disused land in New Doornfontein, taking the first step towards achieving this grand vision, namely the construction of a swimming bath that met all the requirements for an international tournament. The First World War interrupted any further development but the 1920s witnessed impressive expansion to include tennis courts, cricket pitches and rugby football grounds. By the end of the 1920s the council and the Transvaal Rugby Football Union that was a key stakeholder in the development, could proudly claim that they had achieved their dream of establishing an international sports arena for Johannesburg. Ellis Park became a significant urban marker, a symbol of prestige for the fast growing city as well as in the transformation of Johannesburg's urban fabric into a modern city.
\end{abstract}

Key words: Sports development; swimming; tennis; rugby football; cricket; town council; Transvaal Rugby Football Union.

\section{Opsomming}

Na die Suid-Afrikaanse Oorlog (1899-1902) was een van die doelstellings van Johannesburg se Brits-beheerde Stadsraad om voorsiening te maak vir openbare ontspanningsruimtes vir die blanke stadsburgers. Die vestiging en ontwikkeling van Ellis Park as 'n omvangryke sport sentrum was een van hierdie pogings. In 1908 het die stadsraad onbewoonde grond in New Doornfontein gekoop. Daarna is die eerste stap in die bereiking van hul grootse visie geneem, naamlik die bou van 'n swembad wat aan die vereistes vir enige internasionale kompetisie voldoen het. Die Eerste Wêreldoorlog het enige verdere ontwikkeling onderbreek. Die werkike grootskaalse uitbreiding sou in die 1920s plaasvind en het tennisbane, krieket- en rugbyvelde ingesluit. Teen die eindie van die 1920s kon die stadsraad en die Transvaalse Rugby Voetbal Unie, 'n belangrike aandeelhouer in die ontwikkeling, trots daarop aanspraak

* Louis Grundlingh is professor in the department of Historical Studies at the University of Johannesburg. He is currently researching the history of open public spaces in Johannesburg.

How to cite this article: L. Grundlingh, "Transforming a wasteland to a premium sporting arena: The case of Ellis Park, Johannesburg, 1900s-1930s", Historia, 62, 2, November 2017, pp 27-45.

http://dx.doi.org/10.17159/2309-8392/2017/v62n2a2

Copyright: (CThe Author(s). Published under a Creative Commons Attribution Licence. 
maak dat hulle die droom van die vestiging van 'n internasionale sportsentrum vir Johannesburg verwesentlik het. Ellis Park het 'n betekenisvolle stedelike aanwyser geword. Dit het 'n prestige simbool van 'n vinnig groeiende stad geword, 'n simbool van die transformasie van Johannesburg se stedelike omgewing na 'n moderne stad.

Sleutelwoorde: Sport; ontwikkeling; swem; tennis; rugby voetbal; krieket; stadsraad; Transvaal Rugby Voetbal Unie.

\section{Introduction}

After the discovery of gold in 1886, a mining camp was established with no intent of any later development into a town, let alone a city. However, mass migration to the lucrative gold fields soon took off. It became clear that Johannesburg would indeed become a permanent settlement.

This population increase prompted the government of the Zuid-Afrikaansche Republiek (South African Republic) to provide proper town planning. The town surveyor decided on a grid system of small blocks and small stands. The reasoning was to earn as much revenue as possible for the government because rent had to be paid for the stands. This layout limited any provision for urban open spaces. As a result the only significant open spaces that featured in the 1887 plan was the market square. ${ }^{1}$

Until 1902, Johannesburg did not have a town council (hereafter, council). However, at the end of the South African War in 1902, the situation changed. The British government under the leadership of Lord Alfred Milner, took over the administration of Johannesburg from military control and set up an effective municipality, based mainly on the British model. As part of its post-war reconstruction agenda the town council seamlessly integrated British ideas into their vision of Johannesburg's further development. Consequently, it embarked on the provision of proper public services to the fledgling town, such as infrastructure, town planning and the provision of water, electricity and transport. ${ }^{2}$ This was in line with the requirements of an early 20th-century "garden city", ${ }^{3}$ where these services were seen as essential.

Very little academic research has been done thus far on Johannesburg's open spaces and particularly their development into major sport venues. This paper aims to rectify this by investigating the history of Ellis Park. Ellis Park is exceptional in four ways. It never really had the characteristics of a traditional "park". It is one of the first areas in Johannesburg developed on the grounds of an early reservoir which fell into disuse. The initial aim was to develop the grounds into a lake for recreational boating.

1. The other smaller squares were Plein Square, Von Brandis Square and Union Grounds.

2. K. Beavon, Johannesburg: The Making and Shaping of the City (Unisa Press, Pretoria, 2004), pp 71-72.

3. See for example A. Almandoz, "The 'Garden City' in Early Twentieth-century Latin America", Urban History, 31, 3 (2004), pp 437-452; and B. Yuen, "Creating the Garden City; The Singapore Experience”, Urban Studies, 33, 6 (1996), pp 955-970. 
Lastly, from 1905 to the 1930s the grounds were transformed into one of South Africa's most famous fully-fledged sport arenas.

This article argues that it was especially health consciousness amongst Johannesburg's white residents, as well as the prestige of having an open space for first class sport facilities within the context of the "modern city" movement, that prompted this development. The essay further investigates the considerations leading to the council's decision to make this huge investment, as well as the major role of the Transvaal Rugby Football Union (TRFU) in the later development of Ellis Park. Lastly, the essay describes the physical changes to provide for a wide range of sporting activities such as athletics, tennis, rugby football and swimming. This essay does not purport to follow a "history from below" approach but rather it investigates the roles of the political powerful, i.e. Johannesburg's town council and the sport administrators.

Four factors made it possible to develop Johannesburg into a "modern" city. ${ }^{4}$ Because of the huge profits from the gold mines a wealthy urban white elite, the socalled Randlords, or mining magnates, settled and invested in the city. Secondly, there was a strong political will. Thirdly, by the 1900s, population increase amongst whites in the inner-city, noise and pollution led to the outward expansion into the suburbs. Fourthly, as mentioned, the council was ideologically aligned with its counterparts in Britain and subscribed to the British mindset on the necessity of open urban spaces. ${ }^{5}$ This meant that the council ear-marked a number of open spaces for development into public parks ${ }^{6}$ for play, relaxation and organised sport. ${ }^{7}$ The history of urban open spaces and their value, reflects these diverse functions. ${ }^{8}$ In Johannesburg, Ellis Park was a case in point.

${ }^{* *}$ Dust from the mine dumps often made outdoor activities unpleasant. Ironically, though, with moderate weather eight months of the year, Johannesburg's climatic conditions favoured outdoor sport activity. Even though some summer days could be warm to hot, often a late afternoon thunderstorm provided welcome relief. ${ }^{9}$

4. For an exposition and critique of the concept, see M. Berman, All that is Solid Melts into Air: The Experience of Modernity (Verso Press, London, 1983).

5. See L. Grundlingh, "Imported Intact from Britain and Reflecting Elements of Empire: Joubert Park, Johannesburg as a Leisure Space, c. 1890s-1930s", South African Journal of Art History, 30, 2 (2015), pp 104-128.

6. For a discussion on these developments, see L. Grundlingh, "Parks in the Veld'. The Johannesburg Town Council's Efforts to Create Leisure Parks, 1900s-1920s", Journal of Cultural History, 26, 2 (2012), pp 83-105; and Grundlingh, "Imported Intact from Britain”, pp 94-118. Also see G. Torkildsen, Leisure and Recreation Management (Routledge, London and New York, 2005), pp 128-140.

7. See L. Simon, "Open Space and Park Development of Johannesburg”, MA dissertation, University of the Witwatersrand, Johannesburg, 1998, p 2.

8. H. Woolley, Urban Open Spaces (Spon Press, New York, 2003).

9. D. Leyds, A History of Johannesburg: The Early Years (Nasionale Boekhandel, Cape Town, 1964), p 235. 
Supported by excellent weather, Johannesburg's rapid population growth, ${ }^{10}$ and the growing awareness of the advantages of a healthy lifestyle, set the scene for outdoor activities such as tennis, boating, cycling and swimming. ${ }^{11}$ The initial incentive was indeed the need for a municipal swimming pool which had been considered from time to time by the council from as early as 1904 .

The next step was to locate a site for the establishment of Ellis Park. ${ }^{12}$ Initially, considerations such as the lack of a cheap water supply, capital funds for a swimming pool as well as high prices for land, kept the start of the project in abeyance. There was, however, land on which two disused open reservoirs and the Doornfontein brickfields were situated - a "sort of no-man's land" of shacks and hovels occupied by Coloured washerwomen and black people. ${ }^{13}$ This land, between North Park Lane and Eryn Street to the north/north-west; Bertrams Road to the east and South Park Lane and Reservoir Street to the south in New Doornfontein, belonged to the Rand Water Board and the Johannesburg Waterworks Estate and Exploration Company. ${ }^{14}$

A major asset of the grounds was the borehole, at the time the main source of water for the neighbourhood. ${ }^{15}$ The reservoir site comprised 25 acres (10 ha) and had become derelict by the turn of the 19th century. In 1908 the council bought the Rand Water Board's lease for $£ 2500^{16}$ and paid $£ 500$ to the Johannesburg Estates Company for a further 7 acres (2,8 ha) adjoining the reservoir site. ${ }^{17}$ With J.D. Ellis as the driving force, and instrumental in conceiving and converting the neglected site into a playing ground, the council embarked on a comprehensive reclamation scheme with a "grand vision" of an all-encompassing sports centre for Johannesburg. ${ }^{18}$

10. Johannesburg's population growth was as follows: 1896: 73690 (whites: 50 907); 1911: 240131 (whites: 121 857); 1915: 253300 (whites: 123 000); 1921: 295533 (whites: 154 058) and 1936: 537217 (whites: 262 434). See Beavon, Johannesburg: The Making and Shaping of the City, $\mathrm{p} 83$.

11. Leyds, A History of Johannesburg, pp 235-243.

12. In September 1908 the town council named the site after the unrelenting Councillor J.D. Ellis, chairman of the Parks and Estates Committee. See J.R. Shorten, The Johannesburg Saga (Voortrekker Pers, Johannesburg, 1970), p 651; and A.H. Smith, Johannesburg Street Names (Juta \& Co., Cape Town and Johannesburg,1971), p 140.

13. T. Janssens, "The Story of Tennis at Ellis Park, 1911-1994", p 1. (As cited in A. Doukakis and M. Meisel (eds), The Story of Johannesburg's Doornfontein, forthcoming, 2017).

14. This unproclaimed land was known as the Johannesburg Waterworks Reserve No 1. See C. Leigh, "Ellis Park Swimming Bath", p 1. (As cited in Doukakis and Meisel, The Story of Johannesburg's Doornfontein, forthcoming).

15. J.T. Ferreira, J.P. Blignaut, P.J. Landman and J.F. du Toit, Transvaal Rugby Football Union: 100 Years (TRFU Ellis Park, Johannesburg, 1989), p 173.

16. A pound at that time is about $£ 108$ today.

17. Municipal Offices (hereafter MO), Johannesburg (hereafter Jhb), Law Library (hereafter LL), Minutes of the Town Council, 27 May 1908, pp 1224-1227.

18. L.E. Neame, City Built on Gold (Central News Agency, Johannesburg, 1959), p 180; and Historical Papers (hereafter HP), University of the Witwatersrand (hereafter Wits), Johannesburg Public Library Press Cuttings (hereafter PLPC), AF 1913, File 294 Rand Daily Mail, 24 December, 1908. 
One of the first developments towards developing the park into a sports ground was the adaptation of the old storage dam into an artificial lake to be used for boating. Tenders were invited for the right to hire out small boats. The tender was awarded to S.M. Hershfield for 12 months at $£ 20$ a month. Hershfield did not have the sole right of boats on the lake because permission was also granted to private persons to have boats, provided they did not compete with his business. ${ }^{19}$ When the contract expired the next year, the only tender was that of J. Goodman at $£ 10$ per month which the council approved. ${ }^{20}$

Despite the financial losses, it seems the lake would remain a permanent feature in the development of Ellis Park. In August 1910 the town council approved expenditure for the building of a pathway around the lake because the nature of the embankment around the lake was considered dangerous as children might fall into the water. The expenditure would be $£ 974,21$ which was a substantial amount at the time. Even as late as March 1912, the council confirmed its contract with Messrs Bagguley and Stephens "for the completion of the Lake in Ellis Park and the excavation and removal of soil from the Park" ${ }^{22}$ Nevertheless, it seems that nothing came of this plan. The council still maintained its vision to provide for recreation by developing the grounds into rugby football fields, tennis courts, cricket grounds and a swimming pool. At the end of 1908, a report in the Rand Daily Mail noted: "Ellis Park", the thirty acres of town pleasure ground so attractively nestling between the thickly populated sides of the Doornfontein and Fairview Hills, is gradually evolving from the unsightliness of the donga stage." 23

\section{Swimming bath}

The first step towards the "grand vision" was the construction of a swimming bath that would become a central feature. ${ }^{24}$ The decision to build the bath was not taken on a whim. By then the council had already received inquiries from numerous sports clubs to lease portions of ground in Ellis Park for tennis and racquet courts, croquet lawns, football grounds, an ice skating rink and an entertainment hall.25

A Mr Dowsett, of the municipality's architectural branch and a water "fanatic" was tasked to oversee the building. ${ }^{26} \mathrm{~A}$ bath of 150 feet (45.72 metres) long, 100 feet (30.5 metres) wide and 3 feet 4 in ( 1 metre) to 7 feet 4 in (2.2 metres) deep was

19. MO, Jhb, LL, Minutes of Town Council, 5 May 1909, p 253.

20. MO, Jhb, LL, Minutes of Town Council, 22 June 1910, p 1303.

21. MO, Jhb, LL, Minutes of Town Council, 24 August 1910, p 1416.

22. MO, Jhb, LL, Minutes of Town Council, 5 March 1912, p 199. However, the area was later drained, filled up and the ground developed. See also Shorten, The Johannesburg Saga, $\mathrm{p}$ 651.

23. HP, Wits, PLPC, AF 1913, File 294, Rand Daily Mail, 24 December 1908.

24. HP, Wits, PLPC, AF 1913, File 294, Rand Daily Mail, 24 December 1908.

25. MO, Jhb, LL, Minutes of Town Council, 28 July 1909, p 406.

26. HP, Wits, PLPC, AF 1913, File 294, Rand Daily Mail, 24 December 1908. 
proposed. ${ }^{27}$ In July 1908 the council decided to award the tender to Messrs Harper Brothers to build the bath ${ }^{28}$ - at that time the largest in South Africa. In line with the notion to develop Ellis Park into a first class sport venue, the design provided for international competitions. In addition, accommodation for 3000 people, dressing rooms, a children's shelter and ticket office were built. The Rand Daily Mail journalist could write: "The glittering tiles have almost obscured for ever the bottom of what was once Johannesburg's first reservoir for the town's drink." 29

On Saturday 16 January 1909, the first public swimming bath in Johannesburg was inaugurated with a grand gala. The Sunday Times reported:

The best three hours of aquatic sport [that] Johannesburg has yet experienced were enjoyed by over 2000 people ... For the first time the general public had an opportunity of seeing what has been done for them ... The trees and seats which run around two sides of the water were crowded with visitors of both sexes, the threat of rain being insufficient to keep them away from the prospect of sport ... The bath itself is certainly the most adequate structure of its kind in the subcontinent for races ... it seems pretty certain that there will be no lack of public support for fixtures as that of yesterday. ${ }^{30}$

Within three years this prediction proved to be spot-on. The popularity of the bath was evident: "There are glad tidings for a long-suffering public. The swimming baths in Ellis Park are to be opened again for the summer season on Saturday, and preparations are being made for dealing with a rush." 31 Cheap tickets, ${ }^{32}$ open hours from 6 am to $9 \mathrm{pm}$ during summer months and easy access using the tram system, boosted the popularity of the pool.

For the Transvaal Amateur Swimming Association (TASA) the bath met all its requirements for a swimming tournament. Hence it applied to hold the Currie Cup ${ }^{33}$ (swimming tournament) on February 1910. The town council duly approved the application, provided the TASA paid the council $71 \frac{1}{2}$ percent of the total receipts from the sale of tickets. ${ }^{34}$

27. MO, Jhb, LL, Minutes of Town Council, 2 December 1908, pp 1648; and Leigh, "Ellis Park Swimming Bath", p 2.

28. MO, Jhb, LL, Minutes of Town Council, 22 July 1908, pp 1356-1357 and 1361.

29. HP, Wits, PLPC, AF 1913, File 294, Rand Daily Mail, 24 December 1908.

30. HP, Wits, PLPC, AF 1913, File 294, Sunday Times, 17 January 1909.

31. HP, Wits, PLPC, AF 1913, File 447, The Star, 26 March 1912.

32. Prices were as follows. Men: season ticket, 30 shillings; monthly ticket, 7 shillings and sixpence, and a single ticket was one shilling. Women: season ticket, 15 shillings; monthly ticket, 5 shillings; and a single ticket, sixpence. Children under 14 years only paid one penny. See Leigh, “Ellis Park Swimming Bath”, pp 2-3.

33. The Currie Cup is named after its donor, the philanthropist, Sir Donald Currie of the Union Castle Shipping Line. It was originally an inter-club trophy for the water polo championships in Cape Town. Later similar trophies for swimming, rugby football and tennis were donated.

34. MO, Jhb, LL, Minutes of Town Council, 7 July 1909, p 377. 
It was soon apparent that the facilities provided in 1909 were inadequate. Minor additional facilities were added during the 1910s. In 1912 a stand to accommodate 800 spectators was erected at the north side of the park. It was seen as an important addition and welcomed "as a boon to the public ... who throng to the baths as sightseers on Saturdays and Sundays ...".35 It also served as a shelter for the swimming bath against dust during the dust storm season. Ellis Park was gradually getting the trimmings of a proper sporting venue. The 1920s and 1930s, however, saw more substantial additional developments at the bath, inter alia a three-storeyed building with 98 new dressing booths ${ }^{36}$ as well as a tea servery on the lawns. ${ }^{37}$ The swimming bath indeed fulfilled the prophecy in the mayor's minute of 1909 that it would prove to be "a distinct boon to the city".38 Galen Cranz's remark that "swimming pools [in the USA] were more popular than any other single facility", ${ }^{39}$ was certainly true in the case of Ellis Park.

\section{Tennis courts}

Shortly after the swimming bath was finished, the council proposed that Ellis Park should be developed to accommodate tennis and football. ${ }^{40}$ Within a year three tennis courts were built, ${ }^{41}$ thus further adding to the transformation of Ellis Park into a premier sport venue.

In June 1919 the Southern Transvaal Lawn Tennis Association (STLTA) mooted the idea of a tennis court complex at Ellis Park as a memorial to the players who had died in the First World War. ${ }^{42}$ On 5 August 1920, plans for the construction of the memorial courts were submitted to the Parks and Estates Committee and subsequently approved. Another motivation for the council was "to facilitate utilisation of the extended sports grounds and foster the game". ${ }^{43}$ A generous ten-year lease was signed

35. HP, Wits, PLPC, AF 1913, File 447, The Leader, 4 January 1912.

36. HP, Wits, PLPC, AF 1913, File 498, The Star, 23 August 1933.

37. MO, Jhb, LL, Minutes of Town Council, 17 February 1925, p 170.

38. MO, Jhb, LL, Minutes of Town Council, Minutes of His Worship the Mayor for the Mayoral Year Ending October 1909. In 1938, additional facilities were added: a sun-bathing porch, a special pool of 15 feet depth for high-divers, and a paddling pool. See HP, Wits, PLPC, AF 1913, File 447, The Star, 12 January 1938).

39. G. Cranz, "Changing Roles of Urban Parks. From Pleasure Garden to Open Space", Paper, Institute of Urban and Regional Development, University of California, Berkeley, Reprint no. 176, 1978, p 15.

40. MO, Jhb, LL, Minutes of Town Council, 22 June 1910.

41. MO, Jhb, LL, Minutes of Town Council, "Annual Report of the Superintendent of Parks", Minutes of His Worship the Mayor for year ending 30 June 1911, p 90; and The Transvaal Leader, 1912.

42. H.D. Bowker, "The Story of Ellis Park”, (no publisher or place, 1933), p 10. Bowker was president of the STLTA, 1933-1934.

43. MO, Jhb, LL, Minutes of Town Council, 3 May 1922, p 224. 
in April 1922 and by June 1922 eight courts were ready for play. Ellis Park had now become the home of the STLTA.

The STLTA was able to hold the South African Tennis Championships in April 1923 but under difficult conditions because there was no shelter and the officials worked in a split-pole hut, either scorched by the sun or drenched by rain. 44 Nevertheless, seats at the centre court, dressing rooms and a tea kiosk were built by 1925,45 with another 12 courts added by 1932 .

Strict rules formed part of the agreement between the council and the STLTA, the essence of which was to restrict access to white Johannesburgers; the tennis courts could be sublet to smaller clubs except during major tournaments or championships and the park grounds should be open to the (white) public. ${ }^{46}$

As mentioned earlier, in the redevelopment of Ellis Park the council was determined to ensure that the facilities would match international standards. It continued to adhere firmly to this view. According to the chairman of the Parks and Estate Committee, George Hay, "The tennis courts were built in such a manner that Johannesburg would eventually be recognised as the only place in the country for the holding of championships".47 This was indeed the case. Ellis Park hosted an international tennis match between the STLTA and the visiting French team in 1927.48 The council put its money where its mouth was - it budgeted $£ 3,000$ to build an additional stand with a seating capacity of 1500 to 2000 persons. ${ }^{49}$

It is significant to note that the council transferred partial control over the tennis courts to the STLTA. Thus it implemented the policy that sport clubs, when signing a lease with the council, should also take ownership of the sport facilities. This became standard practice for other sporting codes as well.

\section{Rugby football}

A major new development occurred in January 1909, when the TRFU, a popular amateur rugby union, ${ }^{50}$ applied for a lease to approximately twelve acres on the

44. Bowker, "The Story of Ellis Park", p 23; and Janssens, "The Story of Tennis", p 5.

45. HP, Wits, PLPC, AF 1913, File 498, The Star, 9 May 1925.

46. Memorandum of agreement of lease made and entered into by and between the City Council of Johannesburg and Mr W.H Visser (president) and Mrs J.H. Fitzgerald (secretary) of the STLTA, 22 February 1932. See Janssens, "The Story of Tennis", p 4.

47. HP, Wits, PLPC, AF 1913, File 498, Rand Daily Mail, 14 July 1924.

48. MO, Jhb, LL, Minutes of Town Council, 30 August 1927, pp 679. Also see HP, Wits, PLPC, AF 1913, File 320, The Star, 26 April 1928.

49. MO, Jhb, LL, Minutes of Town Council, 30 August 1927, pp 679.

50. The following were some of the clubs that were members of the TRFU: Diggers Rugby Football Club; Germiston Rugby Football Club; Wanderers Rugby Football Club; West Rand Rugby Football Club; East Rand Rugby Football Club; South African School of Mines Rugby Football Club; Pirates Rugby Football Club; Jeppestown Rugby Football Club and 
western side of Ellis Park. The council agreed to a lease of 15 years at $£ 300$ per annum, giving the TRFU all rights to the ground. In addition, significantly, the council expressed the wish that "all first class matches should, as far as possible, be played on this ground". ${ }^{51}$ Thus the Council implicitly confirmed the transformation of the grounds into a sport venue.

The fact that the capital expenditures for the further development of Ellis Park could easily be recovered from the TRFU's rental, buttressed the council's decision. The proposed improvements,

... will naturally enhance the value of the remainder of the park and the surrounding property while the establishment of a properly equipped and controlled sports ground will undoubtedly be to the advantage of the swimming baths and the tramway department. ${ }^{52}$

The council maintained its enthusiastic backing of rugby football after the First World War. In a letter to the TRFU, the mayor of Johannesburg, T.F. Allen, reiterated the council's support for the revival of rugby football. ${ }^{53}$ He felt that:

... there can be no reasonable objection to the game being played with the object of providing a healthy legitimate sport not alone for the players but to those who acquire a great measure of pleasure in watching it. 54

Likewise, at the annual general meeting of the TRFU on 21 May 1918, it confirmed that it would carry on organising games because participation in rugby football

has served the purpose of providing healthy exercise for people obliged to stay here. It was not for the purpose of shielding slackers ... there was no reason why it

Pretoria Rugby Football Club. These clubs were predominantly English speaking and middle class and did very little to popularise rugby amongst Johannesburg's Afrikaans speaking working class. They only became more influential from the 1940s, partly because of the wave of Afrikaner nationalism at the time. Nevertheless, in a "palace revolution" the TRFU's first Afrikaans speaking chairman, J. le Roux, was only elected in 1965. See A. Grundlingh, Potent Pastimes: Sport and Leisure Practices in Modern Afrikaner History (Protea Book House, Pretoria, 2013), pp 59 and 74; and Ferreira et al., Transvaal Rugby Football Union, p 87. Yet, in the meantime, Johannesburg's Afrikaans speakers increasingly formed the bulk of the rugby spectators at Ellis Park.

51. MO, Jhb, LL, Minutes of Town Council, 20 January 1909, pp 20-22; 10 February 1909, pp 81-83 and 8 March1909, pp 121-123.

52. MO, Jhb, LL, Minutes of Town Council, 20 January 1909, pp 20-22.

53. Rugby Football games were abandoned during WWI. See Transvaal Rugby Football Union (hereafter TRFU) Archives, Ellis Park (hereafter EP), paper clippings, The Star, 23 March 1919.

54. TRFU Archives, EP, Mayor's secretary to TRFU secretary, 7 June 1918. He also had ulterior moralistic motives for supporting rugby football. The attendance at the race horse meetings had been on the increase, bringing "under its seductive influence many who were not formerly habitual followers of the sport". 
[the TRFU] should not provide a game like this, and thus prevent them from drifting into other channels perhaps less beneficial. ${ }^{55}$

However, despite the enthusiasm expressed both by the Council and the TRFU, Ellis Park was not yet secured as the permanent venue for rugby football. The council did not fully release its control over Ellis Park. The conditions to the lease were quite stringent. Inter alia, the TRFU could only apply for a liquor license after two years; the tariff for admission to the grounds had to be approved by the council and the TRFU was required to spend at least $£ 2,000$ on improvements to the grounds within the next two years. ${ }^{56}$ In addition, the council insisted that school boys should have free access to play on the ground when it was not in use, ${ }^{57}$ provided they were under the control of the caretaker of the ground. The TRFU was also required to give the civic sports clubs, such as the Athletic Association and Cricket Association, reasonable access. Furthermore, the council retained the right to establish facilities in the park, such as skating rinks, tennis courts, water chutes, a switchback railway, a yachting pond, and swimming baths "or any form of sport and amusement apart from football and cricket". ${ }^{58}$ Not surprisingly then, the TRFU found the terms of the lease unacceptable because there were drastic changes from the original proposals. So much so that the TRFU felt that negotiations were at an end. ${ }^{59}$ Consequently, having no permanent home, the TRFU prolonged its lease of the Wanderers grounds, ${ }^{60}$ and in the light of the stalled negotiations with the council, invested in the Wanderers instead. For example, in 1913 it spent no less than $£ 5,000$ in the erection of a large grand stand. ${ }^{61}$

Nevertheless, negotiations between the council and the TRFU were again afoot 14 years later. The council was prepared to make provision for only one major sporting ground and enquired whether the TRFU was prepared to give up their foothold on Ellis Park in favour of Murray Park and Rhodes Park. TRFU turned down the suggestion and negotiations again stalled. During the negotiations, though, the significant point was made that "it was understood that at some future date Ellis Park might be extended" and the TRFU hoped that "the Council would consider the matter of laying out a rugby ground". ${ }^{62}$

55. TRFU Archive, EP, Paper clippings, The Star, 21 May 1918.

56. MO, Jhb, LL, Minutes of Town Council, 20 January 1909, pp 20-22; 10 February 1909, pp 81-83 and 8 March1909, pp 121-123.

57. In 1913 the TRFU Committee approved the use of all grounds by the schools in the neighbourhood. See TRFU Archive, EP, TRFU Minutes, 14 April 1913 and 28 April 1913.

58. MO, Jhb, LL, Minutes of Town Council, 20 January 1909, 10 February 1909 and 8 March 1909.

59. MO, Jhb, LL, Minutes of Town Council, 219th meeting, 5 May 1909, p 253.

60. The Wanderers Club was the only other prominent sporting venue, mostly catering for cricket. The TRFU paid $£ 50$ for the closed season. See TRFU Archive, EP, TRFU Minutes, 7 February 1913.

61. TRFU Archive, EP, TRFU Minutes, 24 February 1913.

62. TRFU Archive, EP, TRFU Minutes, 8 October 1923. By 1931 the council had put Murray Park at the disposal of the TRFU for school matches catering for the eastern districts. See TRFU Archive, EP, TRFU Minutes, 31 October 1931. The "B" ground was available for 
Four years later, in 1927, this came to fruition. The TRFU applied again to the council for the lease of Ellis Park West. 63 The TRFU had to terminate its lease with the Wanderers Cricket Club ${ }^{64}$ because as a portion of their grounds was expropriated for a new railway station. ${ }^{65}$ It was likely that the remainder would also be forfeited. ${ }^{66}$ The Wanderers grounds were in a sorry state and the TRFU was seeking other headquarters. ${ }^{67}$ The TRFU's negotiator, Mr Reid, remarked that:

in view of the necessity of making provision for future expansion, which would have to be strictly limited if the Union remained at the Wanderers', it would be to the Union's interest if it could secure a home of its own suitable from the viewpoint of accessibility and size. 68

Both parties resumed negotiations to reach an equitable agreement for the lease of Ellis Park grounds. ${ }^{69}$ Members of the TRFU's negotiating team were eager to reach finality as "... time was short and a big task confronted the Union in getting this ground in order."70

They did not have to wait long. Significant changes were made to the 1909 proposals. The lease period was extended to 30 years and the rent was fixed, based on the takings at the gate; the TRFU would upgrade the remaining portion of the recreation centre; the TRFU had the right to sell refreshments, helping it to raise more money for the maintenance of their area of the park which had now become their responsibility. In addition, the TRFU would have full control of the grounds. As a quidpro-quo the council had to arrange for transport facilities to Ellis Park. Subsequently, on 28 June 1927, the two parties signed an amenable agreement. ${ }^{11}$

It is noteworthy that some of the town council's responsibility to provide open space for outdoor activities had now shifted to sporting clubs such as the TRFU. Soon

matches between the sub-unions of the schools. See TRFU Archive, EP, TRFU Minutes, 9 March 1931.

63. TRFU Archive, EP, TRFU Minutes, 21 March 1927.

64. Johannesburg's oldest sporting body.

65. See further discussion below.

66. MO, Jhb, LL, Minutes of Town Council, 8 March 1927, pp 178-179.

67. TRFU Archive, EP, TRFU Minutes, 21 March 1927.

68. TRFU Archive, EP, TRFU Minutes, 29 October 1926.

69. TRFU Archive, EP, TRFU Minutes, 11 June 1927. Also see further discussion below.

70. TRFU Archive, EP, TRFU Minutes, 25 July 1927.

71. MO, Jhb, LL, Minutes of Town Council, 28 June 1927, pp 495. The TRFU leased 113/4 acres for 5 years rent free; the next 5 years $5 \%$ rent; the remainder $10 \%$ of the gross takings. On this see HP, Wits, PLPC, File 320, Rand Daily Mail, 18 August 1927. The particulars were as follows: "(a) certain portion of L1 in extent 1 morgen, 350 square root and 85 square feet of Lot No. 826, North Park Lane in the township of New Doornfontein.

(b) certain portion of L1 in extent 4 morgen, 97 square root of portion of the Farm Doornfontein No. 24, District Johannesburg." These portions were commonly known as Ellis Park West. See TRFU Archives, EP, TRFU Minutes, 10 October 1927. 
afterwards the TRFU commissioned a well-known Johannesburg architect, Gordon Leith, to plan and prepare two fields at Ellis Park. ${ }^{72}$ In addition, the council granted a loan of $£ 5,000$ to complete the stadium. The former quarry was indeed turned into a brand new rugby stadium. ${ }^{73}$ The very next year Ellis Park hosted a test between the Transvaal team and the All Blacks in front of a record crowd of 38,000 spectators. ${ }^{74}$ This suggests that both the TRFU and the town council were committed to a permanent arrangement in the further expansion of Ellis Park. As the TRFU now had a "home", 75 it became a major stakeholder, playing an important role in Ellis Park's future. ${ }^{76}$

By 1929, a substantial amount of $£ 32,000,77$ had been spent on improvements and Ellis Park was ready to host an international football game with the visit of the English Association Football team. ${ }^{78}$ In its annual report of 1935 the TRFU proudly described Ellis Park as the "Mecca of club football". ${ }^{79}$ Ellis Park and Transvaal rugby became synonymous and Ellis Park has been the headquarters of the TRFU for the past more or less 90 years.

\section{Cricket}

The failure of the 1909 negotiations with the TRFU was a temporary setback. Three years later major developments, further confirming the permanency of Ellis Park as a sporting venue, were in the offing. Spearheaded by the city council, the Transvaal Cricket Union (TCU) became increasingly involved. 80

Circumstances at the Wanderers Club, the Johannesburg home of cricket, prompted the development of cricket grounds at Ellis Park. Various factors over a period of more or less 20 years, changed the fortunes of the club's grounds. By 1909, the Wanderers Club was in financial difficulties with its facilities obsolete and insufficient. By the first decade of the 20th century, Johannesburg had spread rapidly to the north where the wealthy white elite and upper-middle class lived in upmarket,

72. The TRFU thus acknowledged the crucial role played by Leith. "His acknowledged genius was stimulated to make his contribution to the game the fine and striking layout of Ellis Park which is now one of the just prides of civic Johannesburg." See TRFU Archive, EP, TRFU meeting, 16 February 1929.

73. TRFU Archives, EP, TRFU Minutes, 10 October 1927; and Ferreira et al., Transvaal Rugby Football Union, pp 39 and 175-177.

74. Ferreira et al., Transvaal Rugby Football Union, p 173.

75. Ferreira et al., Transvaal Rugby Football Union p 37.

76. Rugby became increasingly popular and it seems that the Ellis Park grounds could not meet the demand. Hence the TRFU decided to acquire and maintain the Springfield grounds for junior rugby. See TRFU Archives, EP, TRFU Minutes, 9 May 1924; 21 March 1927 and 13 June 1927. In 1940 the budget for maintenance of the Springfield grounds was $£ 12794$ and for Ellis Park $£ 35126$.

77. Ferreira et al., Transvaal Rugby Football Union, p 39.

78. MO, Jhb, LL, Minutes of Town Council, 28 May 1929, pp 441-443.

79. TRFU Archive, EP, TRFU Annual Report, 31 October 1931, p 3.

80. Grundlingh, "Parks in the Veld", p 21. 
fashionable suburbs. ${ }^{81}$ The Wanderers had become increasingly remote from its largest source of membership. Transport had improved to such an extent that people preferred to go to places distant from the centre of town - where the Wanderers Club was situated - for recreation purposes. ${ }^{82}$ During the First World War and until June 1919 the Wanderers was used as a military hospital. The effect was that the sporting facilities became increasingly dilapidated. In addition, the 16 tennis courts were now so congested that membership of the tennis club had to be restricted. ${ }^{83}$ However, the final nail in the coffin for the grounds was the decision to establish a major railway station on the site. The railways had already blocked all entrances from the town side and threatened to expand the station at the expense of the playing fields. It was therefore no surprise that the TCU transferred its matches to Ellis Park in September 1912.84

At its own cost the TCU built rudimentary dressing rooms for practice and match purposes. These facilities had become totally inadequate. Hence the TCU requested the council to assist with the building of a pavilion, motivating this by adding that:

... the Union is of opinion that not only would it serve to encourage the junior and senior members of the sporting community but it would also be in the Council's interest to form the nucleus of a Sports Ground in Ellis Park (italics added)." 85

The council agreed pay $£ 250$ to this end, provided the pavilion's position would be altered if it interfered with the ultimate layout of the grounds. The club therefore proposed to build a pavilion made of wood and iron so that at any point in the future, it could be redesigned. ${ }^{86}$ White Johannesburg cricket enthusiasts could now look forward to the fruits of the initial steps to transform Ellis Park.

By 1931 the TRFU had already provided extensive facilities at Ellis Park for the TCU. Three turf wickets were in excellent condition and it was hoped that important senior cricket matches would henceforth be played at Ellis Park, ${ }^{87}$ thus enhancing its reputation as a premier facility for major sport events in Johannesburg. The woes of the Wanderers Club thus hugely benefited Ellis Park. ${ }^{88}$

81. Beavon, Johannesburg: The Making and Shaping of the City, pp 88-89, points out that 47 new suburbs were laid out between 1901 and 1906. Residential space accounted for $41 \%$ of the municipal area, most of which lay in the affluent parts of northern Johannesburg.

82. http://www.thewanderersclub.co.za/the-club/history/ "The History of the Wanderers Club", Chapter 9, p 16.

83. http://www.thewanderersclub.co.za/the-club/history/ "The History of the Wanderers Club", Chapter 10, p 8.

84. http://www.thewanderersclub.co.za/the-club/history/ "The History of the Wanderers Club", Chapter 10, p 1.

85. MO, Jhb, LL, Minutes of Town Council, 24 September 1912, p 795.

86. MO, Jhb, LL, Minutes of Town Council, 24 September 1912, p 795.

87. TRFU Archive, EP, TRFU Minutes, 31 October 1931.

88. A further blow was when the TRFU finally moved to Ellis Park in 1928. The Wanderers Club closed down on 27th October 1946. The new premises were opened in 1950. See 


\section{Expansions during the 1920s}

The physical provisions for specific sports have so far been discussed. Yet, the extent to which the "grand vision" of the 1910s came to practical fruition by the 1930s still needs to be unpacked. Whilst the initial layout began in 1905, the comprehensive final plans were only placed before the council and discussed in 1913. The proposal included an oval cycle racing track and even a motor cycle track with running tracks alongside and sprinting tracks inside; a lawn tennis court; a stand of steel construction for 3000 spectators on the high-level ground and uncovered wooden seating for 1200 persons on the sloping bank in front, as well as dressing rooms. The estimated cost was $£ 17,500$. However, just $£ 2,000$ was available at this stage so the council decided to restrict the construction to the uncovered stand and pavilion at a cost of $£ 1,930$ so that it could be available immediately for spectators. The rest of the work would be done in phases. ${ }^{89}$ So, while being committed to provide a range of recreational facilities on the one hand, the council nevertheless had to keep its budget in check.

The council's financial concerns on the further development of Ellis Park as a sport venue were allayed by the knowledge that once the facilities were completed, they would "prove a remunerative investment for the Council". ${ }^{90}$ Several sporting and athletic associations confirmed this, assuring the council of considerable revenue from the use of the grounds. ${ }^{91}$ These considerations made the decision for further improvements easier, ${ }^{92}$ and in the longer term certainly proved to be have been made wisely. A letter to the editor of The Star emphasised that the layout would transform Ellis Park into "what will be one of the best sports grounds in the world". 93

After the First World War, the plans - proposed and approved in 1913 - were resuscitated. The popularity of Ellis Park's facilities, the monetary stability and steady growth, convinced the council to redesign and increase the size of the park to include more sport fields. Furthermore, the growth of sporting activities in Johannesburg necessitated the provision of additional sport centres. In addition to the cycle, running and sprinting track, eight lawn tennis courts, three bowling greens, two croquet lawns, a large refreshment kiosk and a tea lawn and pergola were now included. ${ }^{94}$ George Hay even envisioned a big amphitheatre, contributing to Ellis Park being "recognised as the

http://www.thewanderersclub.co.za/the-club/history/"The History of the Wanderers Club", Chapter 12, pp 3 and 4). Also see TRFU Minutes, 5 March 1928.

89. MO, Jhb, LL, Minutes of Town Council, 29 April 1913, pp 327-328. The TRFU undertook some maintenance work such as renovating the grandstand for $£ 200$ in 1913 . See TRFU Archive, EP, TRFU Minutes, 29 September 1913, p 136.)

90. No author, Johannesburg: Past and Present, 1886-1922 (no publisher, place or date), p 73.

91. MO, Jhb, LL, Minutes of Town Council, 29 April 1913, p 328.

92. MO, Jhb, LL, Minutes of Town Council, 20 January, 1909, pp. 20-22.

93. HP, Wits, PLPC, AF 1913, File 320, The Star, 21 October 1921.

94. HP, Wits, PLPC, AF 1913, File 320, Rand Daily Mail, 24 January 1921. Also see HP, Wits, PLPC, AF 1913, File 320, Rand Daily Mail, 15 November 1921. 
outstanding athletic ground in the country". ${ }^{95}$ An article in the Rand Daily Mail, shared this ambitious view. It requested the council to "convert Ellis Park ... into what it should be - the finest sports arena in the Southern Hemisphere". ${ }^{96}$

From the early 1920s, the Council proceeded to put its money where its mouth was. For example, on the details of the tennis courts the "All England" layout of the courts at Wimbledon was followed as closely as possible. The biggest expense would be the stands to accommodate 9400 persons. The grand total of expenditure added up to $£ 75075 .{ }^{97}$ Whilst everything could not be built immediately, the fact that this grandiose plan was approved, is further evidence that the council was indeed committed to putting Ellis Park on a par with other international sport facilities. Moreover, it confirmed that the council was determined to invest in the health, wellbeing and the leisure activities of Johannesburg's white population.

Constant hustle and bustle at Ellis Park characterised the next 4 years and beyond. Additional seating to accommodate about 1000 spectators was added to the 5400 seats built in $1920 .{ }^{98}$ Because of the demand, extra grandstands with a capacity of 3000 were built the next year. ${ }^{99}$ These new seating arrangements were certainly justified because Johannesburg's white population had almost doubled from 134000 in 1915 to 262434 in $1936 .{ }^{100}$ Requests from sports clubs for further support and facilities inundated the council, demonstrating the popularity of various sporting codes as well as Ellis Park's status as a multi-purpose sport venue. In 1921, Guy Gardner, a journalist for the Rand Daily Mail, reported appreciatively:

Here the surroundings of Doornfontein Swimming Baths are being changed from a melancholy and depressing chaos of deserted brickfield to one of the finest sports centres in the country. ${ }^{101}$

The investment paid off. By 1927 the Council could depend on an income from sponsorships; the leasing out of various parts of Ellis Park; tickets and advertising. ${ }^{102}$ This development took on a new significance. The city's Parks Department, in collaboration with the TRFU, ${ }^{103}$ found itself "boots and all" in the sports business. ${ }^{104}$

95. HP, Wits, PLPC, AF 1913, File No. 498, Rand Daily Mail, 14 July 1924. There was even a small chance that the provision of a motor car racing track was in the offing. See HP, Wits, PLPC, AF 1913, File 320, Rand Daily Mail, 8 September 1920.

96. HP, Wits, PLPC, AF 1913, File No. 452, Rand Daily Mail, 18 June 1926.

97. MO, Jhb, LL, Minutes of Town Council, 23 September 1920, p 646.

98. MO, Jhb, LL, Minutes of Town Council, 21 October 1924, pp 868-869.

99. MO, Jhb, LL, Minutes of Town Council, 24 November 1925, pp 908.

100. Beavon, Johannesburg: The Making and Shaping of the City, p 83.

101. HP, Wits, PLPC, AF 1913, File No. 320, Rand Daily Mail, 24 November 1921.

102. MO, Jhb, LL, Minutes of Town Council, 8 March, 1927, pp 178-181.

103. The TRFU was already "conserving its finances for the new ground at Ellis Park". See TRFU Archive, EP, TRFU Minutes, 30 May 1927.

104. Shorten, The Johannesburg Saga, p 651. 
Evidently very impressed with the massive changes, a reporter of The Star congratulated "our city fathers"

... on their attitude to Ellis Park. In past years the park and its environs were little better than a dust heap and were an eyesore and danger to all beholders. Now, however, matters are radically different ... instead of being repellent it has changed into a place for pleasure and healthy recreation. ${ }^{105}$

The expansion of Ellis Park was in line with the general growth of Johannesburg during the 1920s, but particularly after the Great Depression. Beavon noted that after 1932, Johannesburg was indeed a "city where there was plenty of money for projects, buildings, and public works that caught the imagination of the Council, companies, and private investors". ${ }^{106}$

\section{Ellis Park's multiple uses}

The layout of Ellis Park created addition opportunities. Soon it began to wear an extra coat, accommodating various outdoor activities. In 1929 the promoters of the "Ellis Park Cindrena" applied to the TRFU to use the ground for dirt track racing. The proceeds were to be divided between charitable organisations and the riders "with a view to popularising the sport and advertising the ground". The TRFU, with an eye on obtaining some revenue against the TRFU's running expenses, agreed unanimously in principle to the letting out the ground during the closed season. ${ }^{107}$

As open air games at Ellis Park became extremely popular in the 1930s, the TRFU requested permission from the council to sublet portions of the ground for miniature golf 108 and ring tennis. It emphasised that these pastimes would further enhance the popularity and usage of the grounds. After all, it added, this would "accord with the spirit of the lease whereby the TRFU undertook to render the ground available for the use and service of the public on occasions other than Rugby football".109

Many other sport activities followed suit. Applications for boxing and wrestling tournaments, ${ }^{110}$ as well as the renting out of the grounds for entertainment, became

105. HP, Wits, PLPC, AF 1913, File, The Star, 26 April 1928.

106. Beavon, Johannesburg: The Making and Shaping of the City, pp 94-95.

107. TRFU Archive, EP, TRFU Minutes, 9 November 1928 and 11 March 1929.

108. Most probably inspired by similar developments of miniature golf (also known as Tom Thumb golf) in the USA at the time. See online at: offbeattenn.com/birthplace-minituregolf-tom-thumb-chattanooga/ Accessed 22 November 2016. However, miniature golf quickly declined in popularity. The takings did not meet the running costs and it was closed down. See TRFU Archives, EP, TRFU Minutes, 21931.

109. MO, Jhb, LL, Minutes of Town Council, 17 December 1930, p 1077; and Ferreira et al., Transvaal Rugby Football Union, p 41. For example, the Western Districts Football Association applied to use the ground for its matches on Saturdays if not required by the Union. See TRFU Archive, EP, TRFU Minutes, 23 April 1925.

110. TRFU Archive, EP, TRFU Minutes, 23 March 1931. 
standard practice, ${ }^{111}$ proving the popularity of Ellis Park. Council minutes show that in the "summer season the grounds and stands ... [were] available for summer sports and open-air or outdoor recreation, i.e. cricket, athletics, cycling, professional and amateur boxing, concerts or amusement meetings or receptions". ${ }^{112}$ The African Theatre Limited is an example of an entertainment company that benefited financially from the use of Ellis Park. 113

Because of the evident growth, the TRFU budgeted for further expansion in the 1930s. Extensive additions to accommodate and control huge crowds of up to 55000 who were keen to see international rugby, were in place by the end of the decade. ${ }^{114}$ Although this involved a considerable investment, by 1938 Ellis Park was valued at an impressive $£ 37,832$ and liabilities of $£ 11,000$, 115 proving the TRFU's financial stability to undertake such an enormous development.

\section{Conclusion}

In the context of a very fast growing urban environment, both physically and demographically, the council realised its responsibility to provide for leisure and recreational sporting activities such as swimming, tennis and rugby, albeit exclusively limited to the Johannesburg's white citizens. The most prominent drivers of the initiative were influential members of the council and the TRFU,116 with the support from the numerous sport clubs. Hence the initial aim to transform a wasteland into a recreational lake was soon revised to change it instead into one of South Africa's most famous fully-fledged sport arenas.

This massive undertaking was based on the mindfulness since the 1890s that Johannesburg was indeed becoming a major city. English-speaking power and values, dominated by middle-class white men, governed Johannesburg. Their influence would be paramount in the subsequent general development of the city and specifically in the establishment and character of Ellis Park. The council and the town planners envisioned a modern city with the appropriate accoutrements that would add to the prestige of the city. Buildings in the CBD such as the Rissik Street post office, shopping centres such as The Arcade, the Robinson Bank Building as well the development of open public spaces such as Joubert Park, are ample evidence of the seriousness of the council to achieve this vision. The huge financial investment, especially in the 1920s, the provision for a wide range of sporting activities on a single site and the constant pressure to be on a par with international standards, proves that Ellis Park formed an

111. MO, Jhb, LL, Minutes of Town Council, 23 January 1934, p 69.

112. MO, Jhb, LL, Minutes of Town Council, 27 February 1934, p 160; MO, Jhb, LL Minutes of a Special Meeting, 9 March 1934, p 192; and HP, Wits, PLPC, AF 1913, File 320, Rand Daily Mail, 18 August 1927.

113. TRFU Archive, EP, TRFU Minutes, 9 March 1931.

114. TRFU Archive, EP, TRFU Annual Report, 31 October 1938.

115. TRFU Archive, EP, TRFU Annual Report, Balance sheet, 31 October 1939.

116. J.D. Ellis and G. Hay for the former; and J.H. Crosby and George St Leger Devenish for the latter. 
essential part of this modernisation project. By the early 1930s, Johannesburg could rightfully boast that it could accommodate major international sporting events.

Further developments took place in the 1950s and 1970s when the rugby field and stadium were upgraded. On 6 August 1955 the stadium could accommodate a crowd of more or less 95 000, watching the test between the South African Springboks and the English Lions. ${ }^{117}$ Another momentous event was staged on 24 June 1995, grabbing the attention of South Africans and the world. A fully-packed stadium of spectators watched the test match between the Springboks and the All Blacks. The Springboks beat the All Blacks in extra time and the world watched as President Nelson Mandela donned the extra number 6 jersey worn by the team captain, Francois Pienaar. Albert Grundlingh describes this moment splendidly: "Unprecedented scenes of mass euphoria followed the Springbok victory, unleashing a celebration of an exhilarating excess of hugs and hurrahs, of merriment and madness."118 Almost 90 years after the idea was first broached to establish sporting grounds for Johannesburg's white citizens on a derelict reservoir site, the 1995 victory confirmed Ellis Park's status as a premier sporting arena, probably beyond the imagination of its founders. Moreover, the scale of development of Ellis Park left a distinctive and permanent footprint on Johannesburg's urban landscape.

\section{REFERENCES}

Almandoz, A., "The 'Garden City' in Early Twentieth-century Latin America”, Urban History, 31, 3 (2004), pp 437-452.

Beavon, K., Johannesburg: The Making and Shaping of the City (Unisa Press, Pretoria, 2004).

Berman, M., All that is Solid Melts into Air: The Experience of Modernity (Verso Press, London, 1982).

Bowker, H.D., The Story of Ellis Park, (no publisher or place, 1933).

Cranz, G., "Changing Roles of Urban Parks: From Pleasure Garden to Open Space", Paper, Institute of Urban and Regional Development, University of California, Berkeley, Reprint no. 176, 1978.

Doukakis, A. and Meisel, M. (eds), The Story of Johannesburg's Doornfontein (forthcoming, 2017).

Ferreira, J.T., Blignaut, J.P., Landman, P.J. and Du Toit, J.F., Transvaal Rugby Football Union: 100 Years (Transvaal Rugby Football Union, Ellis Park, Johannesburg, 1989).

Grundlingh, A., Potent Pastimes: Sport and Leisure Practices in Modern Afrikaner History (Protea Book House, Pretoria, 2013).

117. No Author, Johannesbug 100 Jaar (Chris van Niekerk Publikasies, Melville, 1986), p 223; and Grundlingh, Potent Pastimes: Sport and Leisure Practices in Modern Afrikaner History, p 69.

118. Grundlingh, Potent Pastimes: Sport and Leisure Practices in Modern Afrikaner History, $\mathrm{p}$ 129. 
Grundlingh, L., "Imported Intact from Britain and Reflecting Elements of Empire: Joubert Park, Johannesburg as a Leisure Space, c. 1890s-1930s", South African Journal of Art History, 30, 2 (2015), pp 104-128.

Grundlingh, L., '“Parks in the Veld': The Johannesburg Town Council's Efforts to Create Leisure Parks, 1900s-1920s", Journal of Cultural History, 26, 2 (2012), pp 83-105. Janssens, T., "The Story of Tennis at Ellis Park, 1911-1994", pp 1-9. (As cited in Doukakis, A. and Meisel, M. (eds), The Story of Johannesburg's Doornfontein (forthcoming, 2017).

Leyds, D., A History of Johannesburg: The Early Years (Nasionale Boekhandel, Cape Town, 1964).

Neame, L.E., City Built on Gold (Central News Agency, Johannesburg, 1959).

No author, Johannesburg. Past and present, 1886-1922 (no publisher, place or date).

No Author, Johannesbug 100 Jaar (Chris van Niekerk Publikasies, Melville, 1986).

Shorten, J.R., The Johannesburg Saga (Voortrekker Pers, Johannesburg, 1970).

Smith, A.H., Johannesburg Street Names (Juta \& Co., Cape Town and Johannesburg, 1971).

Simon, L., "Open Space and Park Development of Johannesburg", MA dissertation, University of the Witwatersrand, 1998.

Torkildsen, G., Leisure and Recreation Management (Routledge, London and New York, 2005).

Woolley, H., Urban Open Spaces (Spon Press, New York, 2003).

Yuen, B., "Creating the Garden City: The Singapore Experience", Urban Studies, 33, 6 (1996), pp 955-970. 